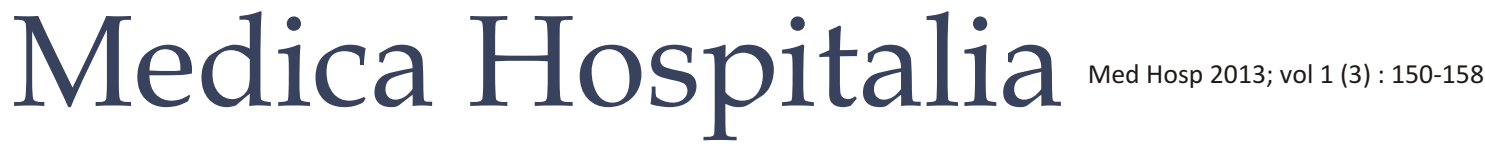

Original Article

\section{Aspek Biomolekuler Apoptosis, Caspase-3 \& RAK pada Pemberian Morinda Citrifolia L (Mengkudu) Tikus Sprague Dawley Diabetes Nefropati yang Diinduksi Streptocotocin (STZ)}

\author{
Indranila KS \\ Bagian Patologi Klinik Fakultas Kedokteran Universitas Diponegoro/RSUP Dr. Kariadi Semarang
}

\begin{abstract}
Abstrak
Latar belakang : Nefropati diabetes (ND) adalah salah satu bentuk komplikasi mikrovaskuler yang sering dijumpai pada penderita diabetes mellitus (DM). Morindacitrifolia $L$ (MC)/mengkudu memiliki komponen zat bioaktif bersifat imunomodulator, imunosupresif, anti inflamasi dan anti apoptosis yang diharapkan dapat memperbaiki fungsi ginjal. Tujuan penelitian ini adalah membuktikan peran $\mathrm{MC}$ dalam memperbaiki fungsi ginjal berdasar pengukuran biomarker RAK, indeks apoptosis, dan caspase-3 pada tikus ND yang diinduksi Streptozotocin (STZ).

Metode : Post test only control group design. Tiga puluh enam ekor tikus Sprague Dawley (SD) diinduksi STZ dosis $40 \mathrm{mg} / \mathrm{kg}$ BB selama 8 minggu, dibagi 6 kelompok, diberi MC dengan dosis $10 \mathrm{mg}$, $20 \mathrm{mg}, 40 \mathrm{mg}$, dan $80 \mathrm{mg}$, dan kelompok kontrol yaitu STZ / kontrol (+) dan (-). Pada akhir penelitian diperiksa RAK, indeks apoptosis, caspase-3.Data dianalisis dengan Mann Whitney dan regresi linier berganda.

Hasil : Didapatkan RAK urin kelompok MC 20 mg lebih rendah dibanding kelompok kontrol $(+)(p=0,04)$. Indeks apoptosis kelompok MC $20 \mathrm{mg}$ lebih rendah dibanding kontrol (+) dengan $p=0,002$. Ekspresi caspase -3 jaringan glomerulus yang tertinggi adalah pada kelompok yang mendapat STZ dan MC yang paling rendah adalah pada kelompok yang mendapat MC $20 \mathrm{mg}$. Didapatkan korelasi positif kuat antara ekspresi caspase-3 dengan indeks apoptosis pada jaringan glomerulus dan tubulus ginjal $(p<0,001)$, hal ini secara tidak langsung dapat menjelaskan apotosis yang terjadi pada jaringan nefron ginjal adalah melalui jalur caspase.

Simpulan : Pemberian Morinda citrifolia L dosis 10, 20, 40, dan 80 $\mathrm{mg} / \mathrm{dL}$ dapat menurunkan status albuminuri berdasarkan pengukuran RAK, indeks apoptosis glomerulus, dan ekspresi caspase-3. Perbaikan fungsi ginjal paling bermakna sekaligus berpengaruh paling kuat untuk perbaikan ND melalui apoptosis glomerulus terhadap penurunan status albuminuria (RAK) didapatkan pada MC konsentrasi $20 \mathrm{mg} / \mathrm{dL}$.
\end{abstract}

Kata kunci : nefropati diabetes, morinda citrifolia L, tikus SD, STZ, apoptosis, caspase-3, RAK

\section{The Effect of Morinda citrifolia L Extract on Kidney Function in Diabetic Nephropathy Streptozotocin-Induced to Sprague Dawley Rat Model}

\begin{abstract}
Background : Diabetic nephropathy (ND) is one form of a common microvascular complications in patients with diabetes mellitus (DM). Morinda citrifolia L (MC) is component of bioactive substances which are immunomodulatory, immunosuppressive, anti-inflammatory and antiapoptosis. MC is expected to improve kidney function in diabetic nephropathy of streptozotocin (STZ)induced to Sprague Dawley rat model. The objective of the study was to proving the role of $\mathrm{MC}$ in the kidney tissue repair ND in STZinduced SD rats.

Methods : used an experimental study post-test only control group design. Thirty-six Sprague-Dawley rats were divided into 6 groups: control (-), control (+), STZ + MC (10, 20,40 and $80 \mathrm{mg} / \mathrm{dL}$ ). Induction of STZ at a dose of $40 \mathrm{mg} / \mathrm{kg}$ for 8 weeks, then given a dose of MC 10, 20, 40 and $80 \mathrm{mg} / \mathrm{dL}$ over 2 weeks. At the end of the study, albumin creatinine ratio (ACR), an index of apoptosis, caspase-3 renal tissue were examined. Statistical analysis using the Kruskall Wallis test, Mann Whitney and multiple linear regression.

Results : Statistical test results showed ACR urine MC 20 mg group was lower than the control group $(+)(p=0.04)$. MC apoptosis index $20 \mathrm{mg}$ group was lower than control $(+)(p=0.002)$. Caspase -3 expression of glomerular tissue were highest for the group that received STZ and MC is the lowest in the group receiving $20 \mathrm{mg}$ of MC. There was strong correlation between expression of caspase -3 with apoptotic index in glomeruli and tubules of the kidney tissue $(p<0.001)$. This may indirectly explain apotosis that occurs in the kidney nephrons network is via caspase pathway. Conclusions : MC extract dose of $10,20,40.80 \mathrm{mg} / \mathrm{dL}$ can improve renal function by improving glomerular apoptotic index, expression of caspase-3. MC dose of $20 \mathrm{mg} / \mathrm{mL}$ is the most optimal dose of MC.
\end{abstract}

Keywords : diabetic nephropathy, Morinda citrifolia L, apoptosis, caspase-3 


\section{PENDAHULUAN}

Nefropati diabetes (ND) merupakan salah satu komplikasi mikrovaskuler diabetes mellitus (DM). Prevalensi ND menduduki angka teratas sebagai penyebab penyakit gagal ginjal terminal, sebanyak $25 \%$ pada penyakiit DM-Tipe 1 dan $30 \%-40 \%$ pada DM-Tipe 2. ${ }^{1}$ Deteksi dini laboratorium dan pengelolaan lebih dini menurunkan insidens ND sehingga menurunkan mortalitas dan moribiditas. ${ }^{2}$

Rasio albumin kreatinin (RAK) merupakan petanda gangguan fungsi ginjal pada ND. ${ }^{3}$ Tolok ukur lain pada gangguan fungsi ginjal adalah apoptosis dan caspase-3. Apoptosis adalah kematian sel yang terprogram di mediatori oleh aktifasi jalur caspase, dalam hal ini terutama caspase-3 dengan hasil pemecahan protein substrat dan fragmentasi DNA. Apoptosis merupakan petanda penting pada sel epitel tubulus dan glomerulus yang mengalami peningkatan pada ND. ${ }^{4}$

Caspase-3 didalam ruang intra membran mitokondria cytochrome-c memediatori aktivasi alosterik dan hepta-ligomerisasi dari molekul adaptor apoptosisprotease activating factor-1 (Apaf-1) membentuk sebuah kompleks apoptosom. Masing-masing apoptosom merekrut tujuh dimer caspase-9 dan menyebabkan aktifasi enzim, membentuk proteolitik self-processing dan katalitik maturasi dari caspase-3 dan secara biokimia maupun morfologi mengaktifkan apoptosis. Caspase-3 memegang peranan penting pada eksekusi apoptosis. ${ }^{5}$

Penanganan ND dilakukan melalui berbagai cara antara lain menjaga kesehatan seoptimal mungkin, menghindari komplikasi, dan menggunakan obat pilihan ND. Namun hal ini tergolong cukup mahal, dan merupakan kendala yang serius, karena ND sering terjadi pada penderita dengan tingkat sosial ekonomi rendah. ${ }^{6}$ Morinda citrifolia L mempunyai berbagai jenis zat bioaktif seperti polisakarida, glikosida flavon, vitamin A, vitamin C, dan xeronin. Kandungan zat bioaktif yang lengkap ini bermanfaat untuk proses perbaikan fungsi ginjal ND antara lain sebagai antioksidan, imunomodulator, antiapoptosis. ${ }^{7}$

Pemberian Morinda citrifolia L dosis aman 10, 20, 40, dan $80 \mathrm{mg} / \mathrm{dL}$ perhari pada tikus Sprague Dawley (SD) yang diinduksi Streptozotocin (STZ), merupakan dosis yang sering digunakan, diharapkan dapat memperbaiki fungsi ginjal yang dideteksi melalui perbaikan RAK, indeks apoptosis, dan caspase $-3 .{ }^{8}$

Penelitian ini bertujuan untuk mengetahui efek pemberian Morinda citrifolia terhadap fungsi ginjal tikus SD yang diinduksi Streptozotocin yang diukur dengan rasio albumin kreatinin, apoptosis, dan caspase-3.

\section{METODE}

Penelitian eksperimental dengan post test only control group design menggunakan hewan percobaan. Subyek penelitian adalah tikus strain Sprague Dawley yang diinduksi dengan Streptozotocin (STZ), Calbiochem ${ }^{\circledR}$ $40 \mathrm{mg} / \mathrm{kgBB}$ untuk menjadikan nefropati diabetes (ND) pada minggu ke 8. Kriteria inklusi adalah tikus berkelamin jantan dengan berat badan 150-300g, kondisi sehat, dan tidak ada kelainan anatomi. Kriteria eksklusi adalah hewan sakit, diare yang ditandai dengan feses tidak terbentuk. Jumlah sampel dihitung berdasarkan rumus besar sampel eksperimental Federer untuk tikus yaitu : $(\mathrm{t}-1)(\mathrm{r}-1)<15$, dengan $\mathrm{t}$ adalah jumlah perlakuan dan $r$ adalah jumlah hewan coba tiap kelompok perlakuan. Penelitian ini dengan dilakukan dengan 4 sub kelompok perlakuan dan 1 kelompok kontrol. ${ }^{9}$

Hewan percobaan sebanyak 36 ekor dibagi secara acak menggunakan rancangan acak lengkat (completely randomized design) dan randomisasi sederhana, menjadi 6 kelompok yaitu kelompok yang mendapat streptozotocin + ekstrak mengkudu (morinda citrifolia) $10 \mathrm{mg}$ (kelompokSTZ + MC10 mg), streptozotocin + ekstrak mengkudu $20 \mathrm{mg}$ (kelompok STZ + MC $20 \mathrm{mg}$ ), + ekstrak mengkudu $40 \mathrm{mg}$ (kelompok STZ + MC $40 \mathrm{mg}$ ), + ekstrak mengkudu $80 \mathrm{mg}$ (kelompok STZ + MC $80 \mathrm{mg}$ ), kelompok yang hanya mendapat streptozotocin tanpa ekstrak mengkudu (kelompok STZ/kontrol +) dan kelompok yang tidak mendapat streptozotocin dan mengkudu (kelompok kontrol -). MC diberikan selama 2 minggu. Keluaran (outcome) yang diharapkan adalah perbaikan fungsi ginjal melalui biomarker RAK (Eliza \& kimiawi), indeks apoptosis (TUNEL), dan caspase-3 (IHC).

Pemeliharan dan intervensi terhadap hewan coba dilaksanakan di LPPT UGM bidang layanan penelitian dan pengembangan hewan percobaan. Pemeliharaan semenjak masa seleksi sampai perlakuan berlangsung dalam waktu 70 hari. Tikus diinduksi STZ $40 \mathrm{mg} / \mathrm{kgBB}$ dalam $0,1 \mathrm{~N}$ citrat buffer sampai $\mathrm{pH} 4,5$. Selanjutnya diambil sampel urin untuk diperiksa rasio albumin dan kreatinin, jaringan ginjal diambil setelah tikus di-sacrified, untuk diperiksa indeks apoptosis dan caspase-3. Pemeriksaan RAK, indeks apoptosis, caspase-3 dilakukan pada laboratorium GAKY-UNDIP Semarang dan laboratorium Patologi Anatomi, Universitas Gajah mada Yogyakarta.

Data hasil penelitan yaitu RAK, indeks apoptosis, caspase-3 setelah terkumpul dilakukan cleaning, coding dan tabulasi selanjutnya di-entry ke dalam komputer. Analisis statistik dengan menggunakan uji beda. Data uji normalitas dilakukan dengan menggunakan ShaphiroWilk test. Bila data tidak normal dilakukan tranformasi data, kemudian dilakukan uji beda one way anova dan uji post hoc-LSD. Uji korelasi RAK, indeks apoptosis, caspase-3 diuji dengan korelasi Spearma. Analisa data kemudian dilakukan menggunakan Mann Whitney dan regresi linier berganda sebagai uji multivariate, dengan tingkat kemaknaan 0,05. Analisis dilakukan dengan SPSS ver 15.0. Penelitian ini telah mendapatkan persetujuan 


\begin{tabular}{|c|c|c|c|}
\hline Parameter & $\begin{array}{c}\text { Sebelum } \\
\text { pemberian STZ }\end{array}$ & $\begin{array}{c}\text { Setelah } \\
\text { pemberian STZ }\end{array}$ & $p ¥$ \\
\hline Berat badan (gram) & $221,3 \pm 18,55$ & $195,5 \pm 26,05$ & $0,4^{\mathrm{a}}$ \\
\hline Kadar gula darah (g/dL) & $84,8 \pm 8,47$ & $348,5 \pm 150,67$ & $<0,001^{\mathrm{a}}$ \\
\hline Volume urin (ml/hari) & $19,6 \pm 9,05$ & $58,4 \pm 34,09$ & $<0,001^{\mathrm{a}}$ \\
\hline
\end{tabular}

aji Wilcoxon;

dari Komisi Etik Kedokteran dan kesehatan Fakultas Kedokteran Universitas Diponegoro dan RS. Dr. Kariadi Semarang.

\section{HASIL}

Pada penelitian ini digunakan 36 ekor tikus SD yang dikelompokkan menjadi 6 kelompok seperti dijelaskan di metode. Selama perlakuan tidak dijumpai hewan coba yang mati. Tabel 1 memperlihatkan berat badan, kadar gula darah dan volume urin tikus sebelum dan sesudah pemberian STZ. Rerata kadar gula darah hewan coba sebelum pemberian STZ adalah dalam batas normal, namun saat 8 minggu setelah pemberian STZ adalah $\pm 4 x$ lebih tinggi dibanding sebelum pemberian STZ, hasil uji statistik menunjukkan peningkatan kadar gula darah tersebut adalah bermakna $(p<0,001)$.

Berdasarkan adanya peningkatan kadar glukosa darah, peningkatan volume urin maka dapat disimpulkan pemberian STZ $40 \mathrm{mg} / \mathrm{kgBB}$ telah dapat menginduksi terjadinya nefropati diabetik pada hewan coba.

Kadar albumin urin pada hewan coba setelah pemberian ekstrak mengkudu berbagai dosis ditampilkan pada gambar 1 .

Pada gambar 2 tampak bahwa penurunan RAK yang terbesar dijumpai pada pemberian MC dengan dosis $20 \mathrm{mg}$. Hal ini juga sesuai dengan hasil analisis pada kadar albumin urin yang juga menunjukkan pemberian MC 20 mg memberikan penurunan kadar albumin urin yang paling besar.

Hasil analisis pada RAK menunjukkan pemberian MC dengan dosis $20 \mathrm{mg}$ dapat menurunkan RAK secara bermakna pada model tikus diabetes yang diinduksiSTZ. Pemberian dosis $40 \mathrm{mg}$ walaupun dapat menurunkan namun penurunan tersebut adalah tidak bermakna, sedangkan dosis MC 10 dan 80 mg menyebabkan RAK yang sedikit lebih tinggi dibanding $\mathrm{K}(+)$ namun tidak bermakna. Persen penurunan RAK yang terbesar dijumpai pada kelompok yang mendapat MC $20 \mathrm{mg}$.

Indeks apoptosis jaringan glomerulus ginjal pada masing-masing kelompok penelitian ditampilkan pada

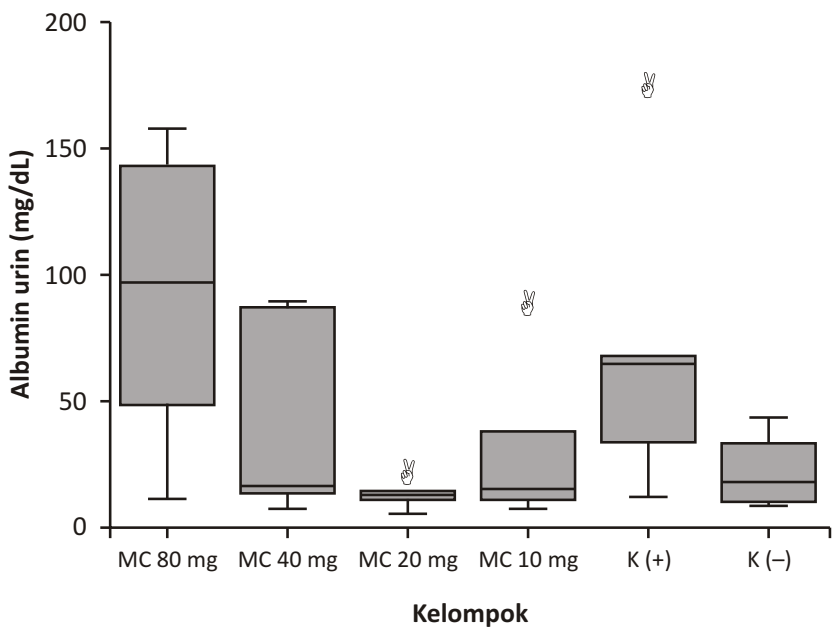

Gambar 1. Perbandingan kadar albumin urin setelah perlakuan pada masing-masing kelompok penelitian. Nilai $p$ menunjukkan derajat kemaknaan perbedaan kadar albumin urin pada kelompok yang mendapat ekstrak mengkudu dibanding kelompok kontrol (+).

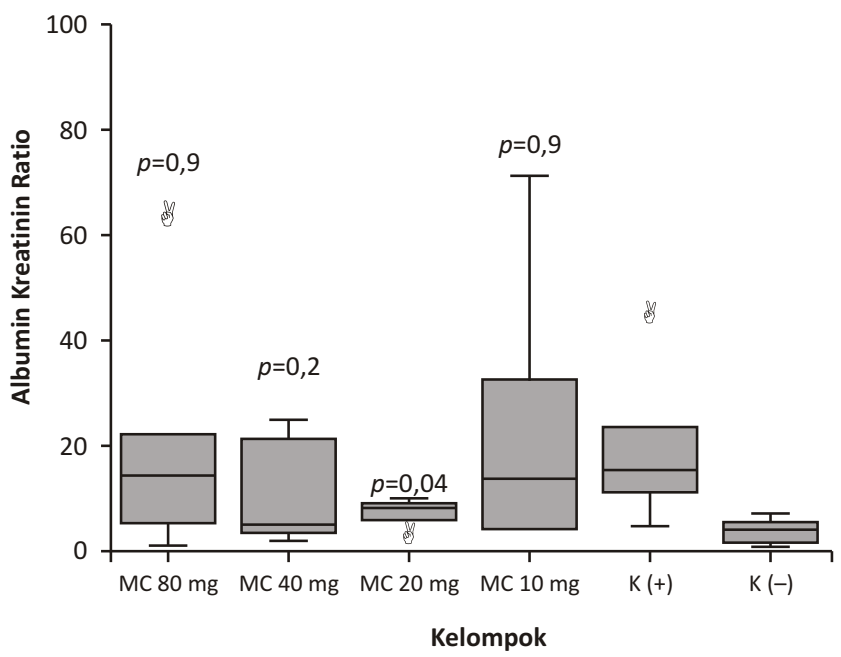

Gambar 2. Perbandingan RAK urin setelah perlakuan pada masing-masing kelompok penelitian. Nilai $p$ menunjukkan derajat kemaknaan perbedaan RAK urin pada kelompok yang mendapat ekstrak mengkudu dibanding kelompok kontrol (+). 


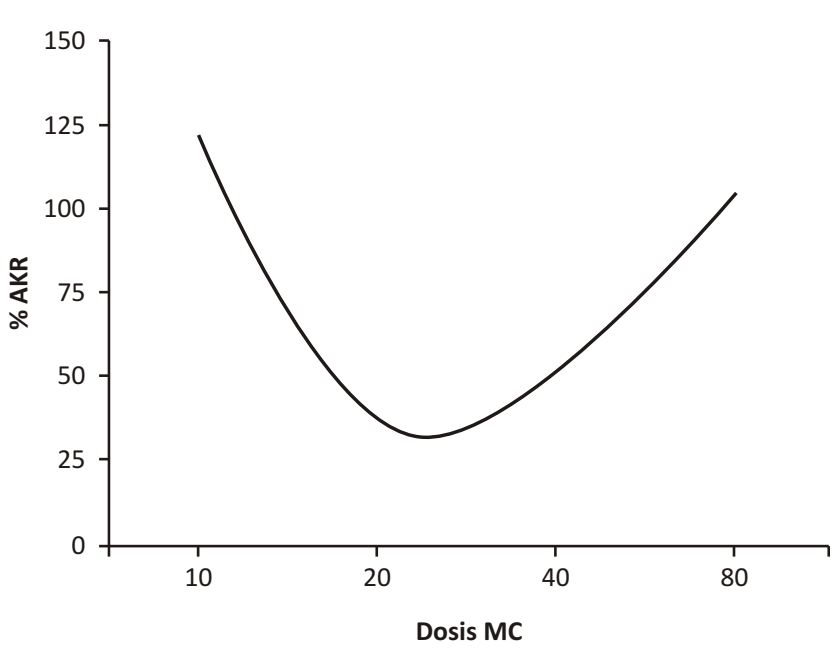

Gambar 3. Persen RAK urin hewan coba yang mendapat pemberian MC dibanding dengan RAK pada kelompok kontrol (+).

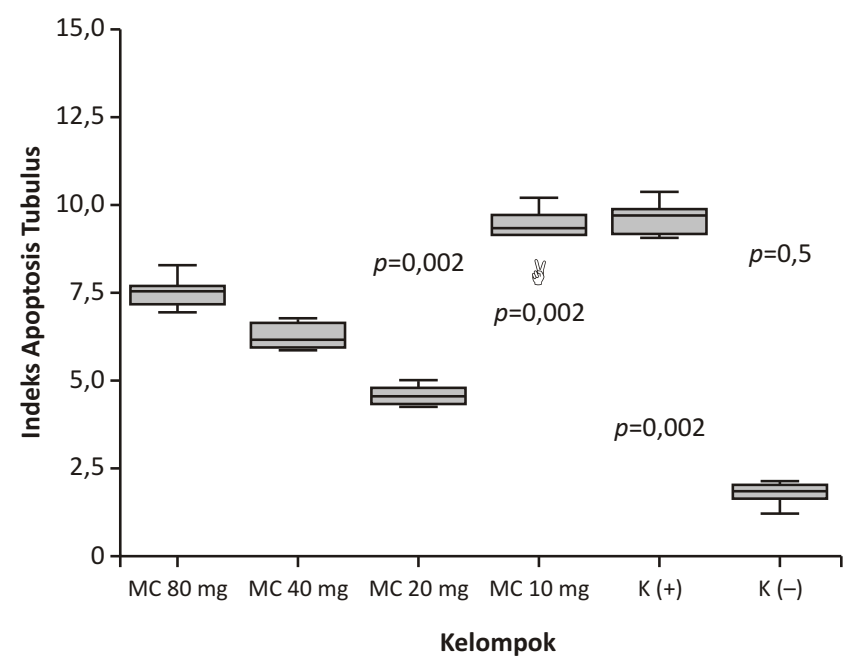

Gambar 5. Perbandingan indeks apoptosis jaringan tubulus ginjal pada masing-masing kelompok penelitian. Nilai $p$ menunjukkan derajat kemaknaan perbedaan indeks apoptosis tubulus ginjal pada kelompok yang mendapat ekstrak mengkudu dibanding kelompok kontrol (+).

gambar 4, sedangkan perbandingan indeks apoptosis jaringan tubulus ginjal pada masing-masing kelompok penelitian ditampilkan juga pada gambar 4.

Ekspresi caspase-3 jaringan glomerulus ginjal pada masing-masing kelompok penelitian ditampilkan pada gambar 6. Ekspresi caspase-3 jaringan glomerulus yang tertinggi adalah pada kelompok yang mendapat STZ dan MC yang paling rendah adalah pada kelompok yang mendapat MC $20 \mathrm{mg}$. Gambar 7 memperlihatkan

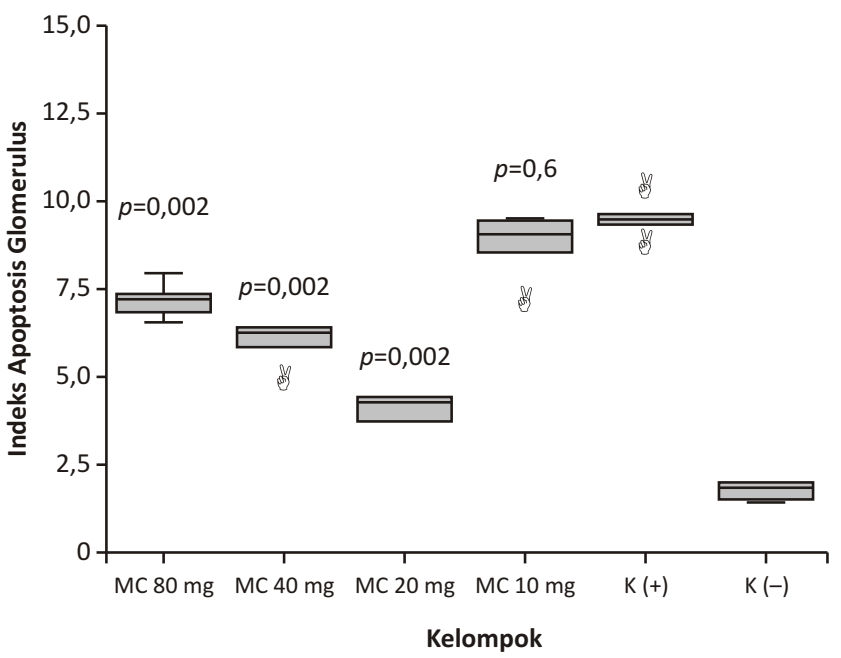

Gambar 4. Perbandingan indeks apoptosis jaringan glomerulus ginjal pada masing-masing kelompok penelitian. Nilai $p$ menunjukkan derajat kemaknaan perbedaan indeks apoptosis glomerulus ginjal pada kelompok yang mendapat ekstrak mengkudu dibanding kelompok kontrol (+).

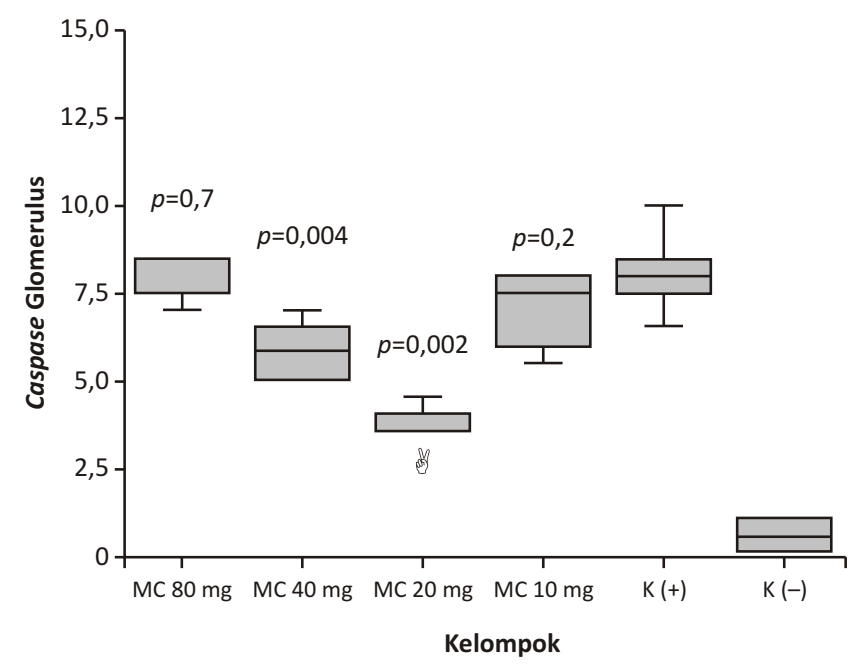

Gambar 6. Perbandingan ekspresi caspase-3 jaringan glomerulus ginjal pada masing-masing kelompok penelitian. Nilai $p$ menunjukkan derajat kemaknaan perbedaan ekspresi caspase-3 glomerulus pada kelompok yang mendapat ekstrak mengkudu dibanding kelompok kontrol (+).

ekspresi caspase-3 jaringan tubulus ginjal pada masingmasing kelompok. Berdasarkan hasil uji statistik dijumpai ekspresi caspase-3 jaringan tubulus ginjal kelompok MC 10, 20, 40 dan 80 mg adalah lebih rendah secara bermakna dibanding kelompok kontrol (+) dengan nilai $p$ masing-masing adalah $p=0,002$.

Disimpulkan ekspresi caspase-3 nefron, glomerulus dan tubulus yang paling rendah adalah pada kelompok MC 20 mg dengan $p=0,002$. 


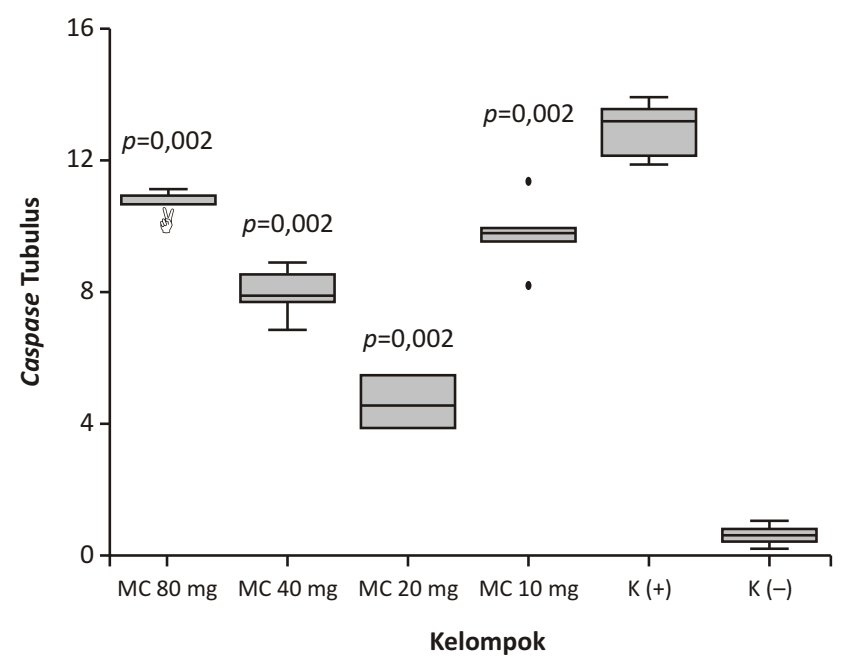

Gambar 7. Perbandingan ekspresi caspase-3 jaringan tubulus ginjal pada masing-masing kelompok penelitian. Nilai $p$ menunjukkan derajat kemaknaan ekspresi perbedaan caspase-3 tubulus ginjal pada kelompok yang mendapat ekstrak mengkudu dibanding kelompok kontrol $(+)$.

\begin{tabular}{|c|c|c|}
\hline \multicolumn{3}{|c|}{$\begin{array}{l}\text { Hasil uji regresi linier berganda faktor-faktor yang } \\
\text { berpengaruh terhadap RAK urin model tikus diabetik } \\
\text { yang diinduksi dengan STZ }\end{array}$} \\
\hline Faktor pengaruh & $\begin{array}{c}\text { Koefisien } \\
\text { regresi }\end{array}$ & $\boldsymbol{p}$ \\
\hline Indeks apoptosis glomerulus & 0,32 & 0,03 \\
\hline Indeks apoptosis tubulus & $-0,39$ & 0,6 \\
\hline Ekspresi caspase-3 glomerulus & 0,167 & 0,5 \\
\hline Ekspresi caspase-3 tubulus & $-0,19$ & 0,6 \\
\hline
\end{tabular}

Analisis untuk menilai faktor-faktor yang berpengaruh terhadap perbaikan fungsi ginjal yang dinilai berdasarkan AKR urin dilakukan dengan uji regresi berganda yang ditampilkan pada tabel 2 .

Berdasarkan hasil analisis uji multivariat pada tabel 2 dapat diketahui indeks apoptosis glomerulus merupakan faktor utama yang berpengaruh terhadap rasio albumin kreatinin urin.

Mekanisme perbaikan fungsi ginjal setelah pemberian MC khususnya dosis $20 \mathrm{mg}$ secara tidak langsung dapat disimpulkan bahwa pengaruh MC terhadap terjadinya apoptosis pada sel glomerulus dan tubulus ginjal tikus diabetes yang diinduksi oleh STZ.

\section{PEMBAHASAN}

Hasil penelitian ini menunjukkan RAK urin tikus ND yang mendapat pemberian MC $20 \mathrm{mg}$ adalah lebih rendah secara bermakna dibanding kelompok kontrol (+). Dosis MC $10 \mathrm{mg}$ tampak belum dapat menurunkan RAK, sedangkan dosis 40 dan $80 \mathrm{mg}$ tampak dapat menurunkan RAK namun penurunannya belum bermakna. Hasil ini menunjukkan bahwa hipotesis MC dapat menurunkan RAK pada tikus ND yang diinduksi dengan STZ adalah terbukti, MC dapat memberikan penurunan RAK urin sehingga mendekati nilai kelompok kontrol (-) adalah $20 \mathrm{mg}$. Hasil penelitian ini juga ditunjang dengan hasil pengamatan pada kadar albumin urin. Kelompok tikus ND yang mendapat MC $20 \mathrm{mg}$ mempunyai kadar albumin urin yang lebih rendah secara bermakna dibanding kelompok kontrol (+). Berbeda dengan hasil pengamatan pada RAK, kadar albumin urin kelompok yang mendapat MC $10 \mathrm{mg}$ dan $40 \mathrm{mg}$ adalah lebih rendah dibanding kelompok kontrol $(+)$, namun hasil uji statistik menunjukkan penurunan tersebut adalah tidak bermakna. Pada kelompok yang mendapat MC 80 mg justru kadar albumin urin adalah lebih tinggi dibanding kelompok kontrol (+). Penelitian ini merupakan penilitian pertama yang melaporkan pengaruh pemberian MC terhadap RAK tikus ND yang diinduksi dengan STZ. Hasil penelitian ini sejalan dengan hasil penelitian sebelumnya oleh Padmavaty yang melaporkan pemberian MC pada tikus ND yang diinduksi oleh STZ dapat menurunkan rasio albumin kreatinin urin. ${ }^{12}$

Mikroalbuminuria pada diabetes berhubungan dengan kerusakan jaringan organ sistem kardiovaskuler dan ginjal. Disfungsi endotel merupakan kondisi yang mendasari kerusakan organ pada sistem kardiovaskuler dan ginjal. ${ }^{13}$ Mikroalbuminuria disebabkan karena peningkatan aliran albumin pada kapiler glomerulus. Peningkatan aliran albumin ini tidak disebabkan oleh peningkatan tekanan pada kapiler glomerulus namun lebih utama karena perubahan ultrastruktur endotel glomerulus akibat disfungsi endotel. Hasil penelitian pada model diabetes binatang menunjukkan kelainan yang dijumpai pada mencit dengan proteinuria adalah kelainan pada selektifitas terhadap muatan listrik molekul albumin. Sel endotel glomerulus menghasilkan beberapa proteoglikan, hyaluronan dan kondroitin sulfat berperan dalam memelihara selektifitas-muatan listrik pada membran filtrasi glomerulus (MFG). Pada ND dijumpai adanya penurunan produksi heparin-sulfat proteoglikan yang menyebabkan perubahan pada fungsi MFG. ${ }^{14}$ Beberapa peneliti sebelumnya belum dapat menjelaskan mekanisme terjadinya mikroalbuminuria pada ND. Hasil penelitian dewasa ini menunjukkan bawa stress oksidatif merupakan mekanisme utama dalam terjadinya komplikasi diabetes. ${ }^{15}$ Hiperglikemia meningkatkan stress oksidatif melalui peningkatan produksi spesies oksigen reaktif (SOR) melalui rantai elektron transport pada mitokondria. SOR memiliki efek langsung terhadap sel melalui peningkatan aktifitas $\mathrm{NF}-\mathrm{kB}$, peningkatan stress oksidatif dan interaksi dengan 
ke-4 jalur kerusakan akibat hiperglikemi seperti yang disebut diatas. ${ }^{16} \mathrm{NF}-\mathrm{kB}$ merupakan protein pengikat DNA yang diperlukan untuk proses transkripsi sebagian besar molekul proinflamasi termasuk molekul adhesi, enzim, sitokin dan kemokin. ${ }^{17}$ Selain SOR, beberapa kondisi lain yang terjadi pada diabetes mengaktifkan $\mathrm{NF}-\mathrm{kB}$ antara lain adalah hiperglikemia dan TNF-a. $\mathrm{NF}-\mathrm{kB}$ dapat disemua jaringan termasuk jaringan nefron ginjal (glomerulus dan sistem tubulus). Aktivasi NF-kB pada jaringan nefron ginjal menyebabkan terjadinya proses inflamasi dan apoptosis. ${ }^{18}$ Perubahan glomerulus yang terjadi adalah penebalan membran basal kapiler, proliferasi mesangial dan nodular glomeruloskelorosis yang merupakan ciri patologi ND. ${ }^{19}$ Pada model diabetes hewan peningkatan NF-KB berhubungan dengan peningkatan ekspresi gen monocyte chemoattractant protein-1 (MCP-1) dan infiltrasi makrofag pada jaringan ginjal. NF-B juga diatur oleh angiotensin II (Ang II). Ang II melalui jalur NF-kB menyebabkan proliferasi sel, apoptosis, fibrosis dan respon inflamasi.

Berdasarkan uraian diatas apoptosis sel glomerulus dan tubulus ginjal mempunyai peran penting dalam patofisiologi ND. Apoptosis pada sel podosit glomerulus dilaporkan sebagai hal yang mendasari terjadi hilangnya podosit. Podosit merupakan sel yang berfungsi khusus untuk mengatur filtrasi glomerulus dan berperan dalam integritas struktur kapiler glomerulus. Apoptosis podosit selanjutnya menyebabkan deplesi podosit secara masif. Hilangnya podosit akan menyebabkan perubahan pada MFG. Apoptosis podosit merupakan peristiwa yang mendahului terjadinya apoptosis pada sel tubulus dan kapiler peritubulus. ${ }^{20}$ Peningkatan glukosa ekstraseluler memicu pembentukan SOR melalui jalur NADPH oksidase. SOR melalui jalur NADPH oksidase dan mitokondria menyebabkan aktivasi protein proapoptosis p38 mitogen-aktivated protein kinase (MAPK) dan caspase $-3 .^{21}$

Pada penelitian ini dijumpai pada kelompok kontrol (+) terjadi peningkatan indeks apoptosis pada sel glomerulus maupun tubulus kurang lebih $5 \times$ lebih tinggi dibanding kontrol (-). Penelitian sebelumnya pada tikus diabetes yang diinduksi oleh STZ juga menjumpai apoptosis sel glomerulus (podosit). Berkurangnya podosit menyebabkan ekspansi mesangial dan glomerulosklerosis. ${ }^{22}$ Penelitian lain melaporkan apoptosis tidak hanya terjadi pada sel glomerulus, namun juga pada sel tubulus. Penelitian tersebut menjumpai adanya over ekspresi katalase pada tubulus proksimal mencit diabetes yang diinduksi STZ. Katalase merupakan suatu antioksidan endogen yang memecah $\mathrm{H} 2 \mathrm{O} 2$ menjadi komponen yang tidak aktif sehingga mengurangi pembentukan SOR. Hal ini merupakan bukti adanya pembentukan SOR pada tubulus proksimal yang lebih banyak dibanding pada glomerulus. ${ }^{23}$ Hasil penelitian tersebut menjelaskan indeks apoptosis pada sel tubulus yang lebih tinggi dibanding glomerulus pada penelitian ini karena stress oksidatif pada sel tubulus adalah lebih besar dibanding sel glomerulus.

Penelitian sebelumnya melaporkan penghambatan NADPH oksidase dilaporkan dapat menghambat terjadinya apoptosis dan mengurangi terjadinya deplesi podosit, miroalbuminuria dan ekspansi mesangial matriks. ${ }^{24}$

Pada penelitian ini dijumpai kelompok yang mendapat MC dosis 20, 40 dan 80 mempunyai indeks apoptosis glomerulus dan tubulus lebih rendah secara bermakna dibanding kontrol (+). Pemberian MC dosis $10 \mathrm{mg}$ tidak memberikan penurunan indeks apoptosis yang bermakna. Selanjutnya hasil penelitian ini juga menunjukkan adanya peningkatan ekspresi caspase-3 pada sel glomerulus dan tubulus. Hal yang menarik adalah ekspresi caspase-3 pada sel tubulus tampak lebih tinggi dibanding pada glomerulus. Hal ini sejalan dengan penelitian sebelumnya yang menjumpai pembentukan SOR lebih banyak pada tubulus ginjal dibanding glomerulus. Caspase-3 merupakan caspase utama yang berperan dalam terjadinya apoptosis. Pada diabetes caspase-3 berperan dalam terjadinya apoptosis sel $\beta$ pankreas. Penelitian Brezniceanu dkk melaporkan caspase-3 juga berperan pada terjadinya apoptosis pada tubulus ginjal. ${ }^{25}$

Adanya penghambatan pada apoptosis dan caspase-3 oleh MC menunjukkan mekanisme terjadinya penghambatan apoptosis pada sel glomerulus dan tubulus ginjal adalah melalui jalur caspase-3. Selain uji korelasi juga menunjukkan adanya korelasi positif antara indeks apoptosis dengan caspase-3. Hal ini berarti semakin tinggi caspase-3 maka indeks apoptosis semakin tinggi. Mekanisme lain yang perlu diteliti adalah manfaat MC sebagai antioksidan. Ada kemungkinan peran MC sebagai antioksidan menghambat pembentukan SOR sehingga menghambat aktivasi NF-B yang selanjutnya memicu apoptosis. ${ }^{26}$ Pada penelitian pendahuluan tentang peran $\mathrm{NO}$ sebagai antioksidan didapatkan hasil yang kurang bermakna $(p=0,4)$. Meskipun demikian terdapat fenomena bahwa caspase-3 sebagai indikator apoptosis pada dosis tinggi tidak bermakna, hal ini berarti ada kemungkinan efek MC terhadap caspase-3 dipengaruhi oleh hal lainnya seperti Bcl-2 dan Bax, serta adanya mekanisme pengaruh jalur intrarenal aktivasi rennin-angiotensin sistem. Seperti telah disebutkan diatas hiperglikemia pada diabetes menyebabkan terjadinya respon inflamasi. Pada penelitian ini terbukti ekspresi IL-1 pada kelompok kontrol (+) adalah lebih tinggi $5 \times$ lipat dibanding kontrol (-). Hal ini menunjukkan adanya peran faktor inflamasi pada jaringan glomerulus ginjal tikus ND. Hasil penelitian ini sejalan dengan hasil penelitian sebelumnya yang juga menjumpai adanya peningkatan IL-1 pada tikus diabetes yang diinduksi dengan STZ. Paparan hiperglikemia jangka panjang menyebabkan peningkatan sitokin 
proinflamasi seperti IL-1 dan TNF-a. Kedua sitokin ini menghambat fungsi dan menyebabkan apoptosis sel $\beta$ pancreas. $^{27}$ Penelitian lain menjumpai adanya peningkatan IL-1 pada jaringan glomerulus dan tubulus ginjal. Peningkatan IL-1 ini menyebabkan peningkatan sintesis kolagen, ekspansi mesangial dan sekresi prostaglandin. ${ }^{28}$ Hasil penelitian ini menunjukkan kelompok yang mendapat MC dosis 10, 20, 40 dan 80 mg memiliki ekspresi IL-1 lebih rendah secara bermakna dibanding kontrol (+). Hal ini membuktikan MC mempunyai potnsi untuk menghambat proses inflamasi pada jaringan glomerulus ginjal.

Pada diabetes selain terjadi peningkatan sitokin proinflamasi juga dijumpai penurunan IL-10 yang merupakan sitokin anti inflamasi. ${ }^{29}$ Hasil penelitian ini menjumpai ekspresi IL-10 kelompok kontrol (+) adalah lebih rendah secara bermakna dibanding kontrol (-). Pada kelompok yang mendapat MC $10 \mathrm{mg}$ tampak ekspresi IL-10 jaringan glomerulus adalah lebih tinggi secara bermakna dibanding kelompok kontrol (+) namun perbedaan yang tidak bermakna dijumpai pada tubulus. Namun pemberian MC $20 \mathrm{mg}, 40$ dan $80 \mathrm{mg} / \mathrm{dl}$ menyebabkan peningkatan eskpresi IL-10 tubulus secara bermakna.

IL-10 merupakan produk dari monosit dan limfosit dan dipandang sebagai anti inflamasi yang utama. IL-10 berperan mengatur sekresi sitokin-sitokin proinflamasi. Sekresi IL-10 biasanya terjadi karena terpicu oleh sekresi sitokin proinflamasi. Hal ini yang menyebabkan terjadinya peningkatan IL-10 pada pasien ND. ${ }^{30}$ Hasil penelitian ini membuktikan pemerikan MC dosis 20, 40 dan $80 \mathrm{mg} / \mathrm{dl}$ dapat meningkatkan respon antiinflamasi. Hal ini menunjukkan MC mempunyai potensi sebagai imunomodulator.

Efek bifasik terlihat pada kurva berbentuk (U-shaped curve) pada AKR, apoptosis, caspase-3. Hal ini menunjukkan efisiensi pengobatan optimal pada dosis $20 \mathrm{mg} / \mathrm{dL}$ atau diantara dosis 10, 40, dan $80 \mathrm{mg} / \mathrm{dL}$. Penting bagi klinisi memperhatikan terhadap dosis optimal. Diperlihatkan pada aktifitas zat bioaktif Morinda citrifolia L dengan adanya biphasic dose-respons curve, perlu diberikan secara proporsional, dimana pada pemberian dosis yang lebih besar akan menurunkan aktifitas, bifasik efek akan memberikan konfigurasi U-shape. Penelitian menunjukkan adanya konsep hormesis sebagai dasar doseresponse dalam biomedik dan toksikologi. Hormesis penting dalam menentukan efek obat, dimana terdapat variasi inter-individual seperti variasiusia, latar belakang keluarga, status nutrisi, dan faktor lain. ${ }^{30,31}$ Hormesis berkontribusi terhadap interaksi kimia. Hal ini disebabkan karena Morinda citrifolia L melebihi dosis efektif dapat bersifat toksik, menyebabkan terjadinya pengurangan respons imun karena mekanisme imunosupresan dari sitem imun tersebut. ${ }^{28-31}$

Penelitian pendahuluan oleh Indranila dkk, terhadap perbaikan fungsi ginjal pada pemberian
Morinda citrifolia L melalui albuminuria, VEGF, TGF $\beta$, NO menunjukkan adanya korelasi antara status albuminuria dan nitrit oksida (NO) dengan nilai $p=0,4$; VEGF dengan nilai $p=0,3$, dan korelasi bermakna TGF- $\beta$ $(p=0,06)$. Zeisberg $\mathrm{dkk}$ mengatakan terdapatnya pengaruh penurunan TGF- $\beta$ terhadap perbaikan injury ginjal. $^{32}$ Demikian juga peningkatan IL-10 pada pemberian $\mathrm{MC}$ dosis $20 \mathrm{mg} / \mathrm{dL}$ secara bermakna tersokong oleh penelitian terdahulu. ${ }^{33}$ TGF- $\beta$ sebagai sitokin growth factor memiliki efek sinergis dengan IL-10 sebagai sitokin antiinflamasi.

Pada penelitian pendahuluan MC pada dosis $20 \mathrm{mg} / \mathrm{dL}$ dengan berbagai zat bioaktif senyawa flavonoid mampu menghambat terbentuknya NO, AGES sehingga mengurangi densitas HS-PG. Peningkatan laminin pada membran basalis karena berkurangnya HS-PG akibat biosintesis glikoprotein. Sebagai antioksidan, flavonoid berperan menghambat produksi VEGF, TGF- $\beta$ dan NO. ${ }^{34}$ MC mengurangi ekspresi VEGF, senyawa flavonoid memiliki ikatan lemah terhadap ikatah HIf-1a dibandingkan dengan ikatan ATP pada proteinkinase, sehingga ekspresi VEGF tidak dihambat. MC memacu angiogenik dapat dilihat dari skor yang mencerminkan interaksi senyawa dan protein target yang memiliki aktifitas penghambatan angiogenesis. Jalur sinyal TGF- $\beta$ pada penyakit ginjal merangsang perspektif terapi dan penatalaksanaan akan pencegahan progresifitas ND, melalui normalisasi disfungsi sel dan produksi TGF- $\beta$ pada tikus SD yang diinduksi STZ. ${ }^{35}$ Flavonoid mencegah cedera akibat radikal bebas melalui berbagai cara, salah satunya melalui radical scavenger, mengurangi radikal, menstabilkan ROS melalui ikatan reaktivasi radikal bebas. Menurut Steer, 2006, Morinda citrifolia L pada dosis $20 \mathrm{mg} / \mathrm{dL}$ memiliki efek proinflamsi dengan IFN- $\gamma$ dan sitokin IL-1 dan sebaliknya memiliki efek anti inflamasi dengan sitokin Il-10. ${ }^{36}$ Morinda citrifolia dosis $20 \mathrm{mg} / \mathrm{dl}$ menurunkan RAK. Pemberian Morinda citrifolia L melebihi dosis efektif $20 \mathrm{mg} / \mathrm{dL}$ merupakan dosis melebihi dosis yang dianjurkan, mungkin bersifat toksik, ${ }^{37}$ hal ini masih memerlukan pembuktian pada penelitian lebih lanjut.

\section{SIMPULAN}

Pemberian ekstrak Morinda citrifolia L pada dosis tertentu terbukti memperbaiki fungsi ginjal pada tikus SpragueDawley ND yang diinduksi Streptozotocin. Hal ini terbukti bahwa: MC pada konsentrasi $10 \mathrm{mg}, 20 \mathrm{mg}$, $40 \mathrm{mg}$, dan $80 \mathrm{mg} / \mathrm{dL}$ dapat memperbaiki fungsi ginjal ND.

a. Pemberian Morinda citrifolia L dosis 10, 20, 40, $80 \mathrm{mg} / \mathrm{dL}$ dapat menurunkan status albuminuri berdasarkan pengukuran RAK, menurunkan indeks apoptosis, ekspresi caspase-3, secara bermakna.

b. Pemberian ekstrak Morinda citrifolia L dapat memperbaiki fungsi ginjal paling bermakna pada konsentrasi $20 \mathrm{mg} / \mathrm{dL}$. 
c. Pemberian Morinda citrifolia L memberikan pengaruh paling kuat untuk perbaikan ND melalui apoptosis glomerulus terhadap penurunan status albuminuria berdasarkan pengukuran RAK pada dosis $20 \mathrm{mg}$.

Saran pemberian dosis Morinda citrifolia L (MC) yang dianjurkan adalah $20 \mathrm{mg} / \mathrm{dL}$ pada tikus, penggunaan MC perlu dipantau pemeriksaan rasio albumin kreatinin (RAK), serta perlu dilakukan penelitian lanjutan pada manusia, dengan dosis $100 \mathrm{mg} / \mathrm{dL} / \mathrm{kgBB}$, yang merupakan hasil konversi dosis $20 \mathrm{mg} / \mathrm{dL}$ pada tikus.

\section{UCAPAN TERIMA KASIH}

Terima kasih kepada Dirjen Dikti yang telah memberikan bantuan sehingga terselesaikannya penelitian ini.

\section{DAFTAR PUSTAKA}

1. Bandiara R. Penatalaksanaan nefropati diabetik. Dalam simposium endokrinologi klinik VII. Bandung, Unpad, 2010, hal 48-72.

2. Remuzzi G, Perico N, Macia M, Ruggenenti P. The role of rennin-angiotensisn aldosterone system in the progression of chronic kidney disease. Kidney Int 2005;68:S57-65.

3. Okada H, Kalluri R. Cellular and molecular pathways that lead to progression and regression of renal fibrogenesis. Curr Mol Med 2005;5:467-74

4. Suztak K, Raff AC, Schiffer M, Bottinger EP. Glucose-Induced Reactive Oxygen Species caused Apoptosis of Podocytes and Podocyte depletion at the onset of diabetic nephropathy. Diabetes 2006;55:225-33.

5. Alikhani Z, Alikhani M, Boyd CM, Nagao K, Trackman PC, Graves DT. Advanced glycation end products enhace expression of pro-apoptotic genes and stimulate fibroblast apoptosis through cytoplasmic and mitochondrial pathways. J Biol Chem 2005; 280:12087-95.

6. Zuhud. Kembali kealam memanfaatkan obat asli Indonesia, suatu kajian etnofarmakologi. Seminar Nasional Biologi XVI. Himpunan Biologi Indonesia, Bandung 2000.

7. Wang MY, West BJ, Jensen CJ, Nowicki D, Su C, Palu AK, Anderson G. Morinda citrifolia (Noni): a literature review and recent advances in noni research. Acta Pharmacol Sin 2002;23:1127-41.

8. Potterat O, Hamburger M. Morinda citrifolia (Noni) FruitPhytochemistry, Pharmacology, Safety. Planta Med 2007;73:191-9.

9. Wang M, Kikuzaki H, Jin Y, Nakatani N, Zhu N, Caiszar K, Boyd C, Rosen RT, Ghai G, Ho CT. Novel glycosides from noni (Morinda citrifolia ). J Nat Prod 2000;63:1182-3.

10. Rao UM, Subramanian S. Biochemical evaluation of antihyperglicemic anti oxidative effects of Morinda citrifolia; fruit extract studied in Streptozotocin induced diabetic rats. Medicinal Chem Res 2009;18:433-66.

11. Olajide OA, Awe SO, Makinde JM, Morebise OLUG. Evaluation of the anti-diabetic property of Morinda lucida leaves in Streptozotocin-diabetic rats. J of Pharmacy and Pharmacol 1999;51:1321-4.

12. Lenzen S. The mechanisms of alloxan and streptozotocin induced diabetes. Diabetologia 2008;51:216-26.

13. Cha DR, Kim NH, Yoon JW, Jo SK, Cho WY, Kim HK, Won NH. Role of vascular endothelial growth factor in diabetic nephropathy. Kidney Int 2000;77:S104-12.
14. Brownlee M. Biochemistry and molecular cell biology of diabetic complications. Nature 2001;414:813-20.

14. Sanz A, Santamaria B, Ruiz-Ortega M, Egido J, Ortiz A. Mechanisms of renal apoptosis in health and disease. J Am Soc nephrol 2008:19: 1634-42.

15. Breyer M, Harris R. Diabetic nephropathy. In Mount Db, Pollak MR, editors. Molecular and genetic basis of renal disease. Philadelphia: Saunders Elsevier, 2008:p391-417

16. Bursell SE, King GL. Protein kinase-C activation, development of diabetic vascular complications, and role of vitamin $\mathrm{E}$ in preventing these abnormalities. Diabetes Management, 2000:241-63.

17. MM, Husein AM, Sherif IO, Ali SS and Mohamed HE. Renal ischemia/reperfusion injury in type II DM: Possible role of proinflamatory cytokines, apoptosis, and nitric oxide. J Physiol and Patophysiol 20111;2(1):6-7

18. Viberti GC. Hypertension and the renal vascular complications of diabetes: a structural basis to guide management. Schwiz Med Wochenschr 1994;124:1938-40.

19. Baba T, Neugebauer S, Watanabe T. Diabetic nephropathy. Its retlationship to hypertension and means of pharmacological intervention. Drugs 1997;54:197-234.

20. Saikumar P, Venkatachalam MA. Role of apoptosis in hypoxic/ischemic damage in the kidney. Semin Nephrol 2003;23:511-21.

21. Mattix HJ, Hsu CY, Shaykevich S, Curhan G. Use of the albumin/creatinine ratio to detect microalbuminuria: implication of sex and race. J Am Soc Nephrol 2002;13:1034-39

22. Liadis N, Murakami K, Eweida M, Elford AR, Sheu L, Gaisano HY, Hakem R, Ohashi PS, and Woo M. Caspase-3-dependent $\beta$ cell apoptosis in initiation of autoimmune diabetes mellitus. Moll and cell Biol 2005;25(9):3620-9.

23. Savill J. Apoptosis and the kidney. J Am Soc Nephrol 1994; 5:12-21

24. Heinicke R. The pharmacologically active ingredient of Noni. Bulletin of the National Trop Botanical Garden 1985;15:10-4.

25. Frigo DE, Duong BN, Melnik LI, Schief LS, Collins-Burow BM, Pace DK. Flavonoid Phytochemicals Regulate activator protein-1 signal transduction pathway in endometrial and kidney stable cell lines. J of Nutrition 2002;132:1848-53

26. Kitamura M, Ishikawa Y. Oxidant induced apoptosis of glomerular cells: intracellular signaling and its intervention by bioflavonoid. Kidney Int. 1999;56:1223-29.

27. Kashihara N, Sugiyama H, and Makino H. Mechanisms for induction of apoptosis and glomerular disease. Nephrol Dial Transplant 1999;14:52-4.

28. Meier M, Menne J, Heller H. Targetting the protein kinase C family in diabetes kidney. Lessons from analysis of mutant mice. Diabetologia 2009;52:765-75.

29. Hirazumi A, Furusawa E. An immunomodulatory polysaccharide-rich substance from the fruit juice of Morinda citrifolia (noni) with antitumour activity. Phytotherapy Research 1999;13:380-7

30. Calabrese EJ, and Baldwin. Defining hormesis. Human \& experimental Toxicology 2001;21:91-97.

31. Mattson MP. Hormesis Defined.Available at www.ncbi.nlm.nih.gov/pmc/srticles/PMC2248601.

32. Indranila KS, Judiono and Theophillus W. Effect of Multidoses of Streptozotocin diabetogenic induced Sprague Dawley rats on hyperglycemia and microalbuminuria. In Novel material and drug design international seminar on chemistry. Departement of Chemistry Diponegoro University 2010.

33. Li RW, Myers SP, Leach DN, Lin GD, Leach G. A cross-cultural study : anti-inflammatory activity of Australian and Chinese plants. JEthnopharmacol 2003;85:25-32. 
34. Lukacinova A, Mojzis J, Benacka R, Keller J, Maguth T, Kutila P, Vasko L, Racz O, and Nistiar F. Preventive Effects of flavonoids on Alloxan-Induced diabetes Mellitus in rats. Actavet.BRNO 2008;77:175-82.

35. Kim MH. Flavonoids inhibit VEGF/bFGF-induced angiogenesis in vitro by inhibiting the matrix-degrading proteases. J Cell Biochem 2003;89(3):529-38.
36. Steer SA, Scarim AL, Chambers KT, and Corbett JA. Interleukin 1 Stimulates $\beta$-Cell Necrosis and Release of the Immunological Adjuvant HMGB1. Plos Med. 2006;3(2):17.

37. Nelson SC. Morinda citrifolia (Noni) Species profiles for pacific Island Agroforesty . Available at www.traditionalree.org. 